\title{
Significance of Lead aVR ST Segment Elevation in Patients Presenting with NSTEMI Acute Coronary Syndrome as a Predictor of Left Main Coronary Artery Lesions
}

\author{
AMR ABO EL-FOTOH, M.D. and AHMED SHAHEEN, M.D. \\ The Department of Cardiology, Shebin El-Kom Teaching Hospital, Egypt
}

\begin{abstract}
Background: Left main coronary artery (LMCA) occlusion is a serious clinical condition. Despite its low incidence, the prognosis is grave. It may present as sudden death, complete heart block, shock and/or acute coronary syndrome (ACS).

Aim of Study: The study aimed to investigate the value of ST-segment elevation in lead aVR in the surface ECG as a predictor of LMCA lesions in patients suffering from nonST-segment elevation myocardial infarction (NSTEMI) and its relation to the severity of LMCA.
\end{abstract}

Material and Methods: It is a retrospective study including patients admitted to CCU in Banha University Hospital, Shebin El-Kom Teaching Hospital and National Heart Institute. A total number of 100 patients with the diagnosis of NSTEMI ACS who had significant LMCAD on coronary angiography were included in this study; the patients were classified according to the presence or absence of ST-segment elevation of $>0.05 \mathrm{mV}$ in lead aVR into two groups:

- Group 1: Patients with isoelectric ST-segment in lead aVR or with ST-segment elevation of less than $0.05 \mathrm{mV}$.

- Group 2: Patients with ST-segment elevation of $0.05 \mathrm{mV}$ or more in aVR.

Results: Patients with elevated ST segment more than 1 is significantly higher among patients who died than those who are still alive $(p<0.001)$. Twenty eight patients $(37.8 \%)$ had Left Main coronary disease in group 2, less than $80 \%$ stenosis compared to $18(75 \%)$ patients in group 1.

While 46 patients $(62,2 \%)$ had Left Main stenosis more than $80 \%$ In group 2, compared to 6 patients (25\%) in group 1 , the differences between subgroups were statistically significant difference ( $p$-value $<0.001)$.

Conclusion: ST-segment elevation in lead aVR is a sensitive prognostic indicator in detecting left main coronary artery lesions of patients suffering from non-ST-segment elevation myocardial infarction (NSTEMI).

Key Words: Left main coronary artery (LMCA)-Acute coronary syndrome (ACS).

Correspondence to: Dr. Amr Abo El-Fotoh, The Department of Cardiology, Shebin El-Kom Teaching Hospital, Egypt

\section{Introduction}

ACUTE coronary syndrome (ACS) is usually one of three diseases involving the coronary arteries: ST elevation myocardial infarction (30\%), non ST elevation myocardial infarction (25\%), or unstable angina (38\%) [1]

Left main coronary artery (LMCA) occlusion is a serious clinical condition. Despite its low incidence, the prognosis is grave. It may present as sudden death, complete heart block, shock and/or acute coronary syndrome (ACS). Surgery is usually too late to initiate, so that percutaneous coronary intervention (PCI) is utilized to obtain immediate vessel patency. However, this modality is associated with a high mortality and restenosis rate. Early recognition and emergent PCI may be lifesaving [2].

Analysis of lead aVR has its value in the classification of acute inferior and lateral myocardial infarction (MI) [3], and the prediction of left ventricular dysfunction after anterior MI. However, the prognostic significance of the ST-segment elevation in lead aVR on the initial ECG is unknown [4]

Panovský, R., et al., stated that recognition of patient with possible (LMCAD) prior to catheterization has led to a much lower death rate related to diagnostic catheterization and help to select appropriate treatment strategy.

\section{Material and Methods}

It is a retrospective study including patients admitted to CCU in Banha University Hospital, Shebin El-Kom Teaching Hospital and National Heart Institute. From November 2014 to November 2015. 
A total number of 100 patients with the diagnosis of NSTEMI ACS who had significant LMCAD on coronary angiography were included in this study; those patients were classified according to the presence or absence of ST-segment elevation of $\geq 0.05 \mathrm{mV}$ in lead aVR into two groups:

- Group 1: Patients with isoelectric ST-segment in lead aVR or with ST-segment elevation of less than $0.05 \mathrm{mV}$.

- Group 2: Patients with ST-segment elevation of $0.05 \mathrm{mV}$ or more in aVR.

Patients were excluded from analysis if:

1 - They had any of the following conditions precluding ST elevation on ECG, i.e.:

- Left bundle branch block.

- Right bundle branch block.

- Left ventricular hypertrophy.

- Digitalis therapy.

- Ventricular pacing.

- Prior history of coronary artery bypass grafting (CABG) surgery.

2- Associated heart disease other than coronary artery disease.

3- Cardiac rhythm other than sinus rhythm.

4- Left main equivalent disease it is defined as a $75 \%$ or greater stenosis of the left anterior descending coronary artery before any major first septal perforator or anterolateral vessel and a $75 \%$ or greater stenosis of the left circumflex artery before any major marginal branch in the absence of $50 \%$ or greater left main stenosis [6].

\section{Results}

\section{1- Patient's demographic criteria:}

One hundred patients experienced NSTEMI and had documented significant LMCA disease were included in this study out of 3500 patients presented with NSTEMI, 68 males and 32 females; they were divided into two groups according to ST-segment elevation in lead aVR as follows:

- Group (1): No elevation in lead aVR, or elevation $<0.05 \mathrm{mV}$. This consisted of 26 patients who are represent $26 \%$ of all the patients, with a mean age of 57.54 \pm 9.27 years 12 males and 14 females.

- Group (2): $\geq 0.05 \mathrm{mV}$ elevation in lead aVR. This consisted of 74 patients who represent $74 \%$ of all the patients, with a mean age of $59.84 \pm 7.48$ years 56 males and 18 females.
There were statistically significant differences between both groups regarding sex distributions but not with age as shown in Table (1).

\section{2- Risk factors for ischemic heart disease:}

As regard distribution of risk factors for ischemic heart disease among both groups; hypertension was present in $18(69.2 \%)$ patients in group 1 and in $40(54.1 \%)$ patients in group 2, diabetes mellitus was present in $30(40.5 \%)$ patients in group 2 and $12(46.2 \%)$ patients in group 1. dyslipidemia was found more evident in group 2, $60(81.1 \%)$ patients versus $16(61.5 \%)$ patients in group 1, as regard positive family history for IHD it was found in 26 (35.1\%) patients in group 2 and in $10(38.5 \%)$ patients in group 1, while smoking was nearly equally present in the two groups, $16(61.5 \%)$ patients in group 1 and $46(62.2 \%)$ patients in group 2. But none of these differences were statistically significant as shown in Table (1) except for dyslipidemia.

Table (1): Demographic data and risk factors for IHD of the patients among the two study groups.

\begin{tabular}{lllll}
\hline & $\begin{array}{c}\text { Group (1) } \\
\mathrm{n}=26\end{array}$ & $\begin{array}{c}\text { Group (2) } \\
\mathrm{n}=74\end{array}$ & $\begin{array}{c}\text { Statistical } \\
\text { analysis } \\
\text { result }\end{array}$ & $\begin{array}{c}\text { Sig. } \\
p \text {-value }\end{array}$ \\
\hline Age in Yr. & $57.54 \pm 9.27$ & $59.84 \pm 7.48$ & $t=1.27$ & $\geq 0.05$ \\
Male gender & $12(46.2 \%)$ & $56(75 \%)$ & $\mathrm{x}^{2}=7.71$ & $<0.05$ \\
Smoking & $16(61.5 \%)$ & $46(62.2 \%)$ & $\mathrm{x}^{2}=.003$ & $\geq 0.05$ \\
Hypertension & $18(69.2 \%)$ & $40(54.1 \%)$ & $\mathrm{x}^{2}=1.82$ & $\geq 0.05$ \\
+Family History & $10(38.5 \%)$ & $26(35.1 \%)$ & $\mathrm{x}^{2}=0.09$ & $\geq 0.05$ \\
Diabetes millets & $12(46.2 \%)$ & $30(40.5 \%)$ & $\mathrm{x}^{2}=0.25$ & $\geq 0.05$ \\
Dyslipidemia & $16(61.5 \%)$ & $60(81.1 \%)$ & $\mathrm{x}^{2}=4.03$ & $<0.05$ \\
\hline
\end{tabular}

$(t)$ Is the value of the " $t$-Test".

$\mathrm{x} 2=$ Chi-square value, data are means $\pm \mathrm{SD}$ or Number.

\section{3- Electrocardiographic criteria:}

ECG was done to all patients on admission and the following criteria were analyzed in each group as shown in Table (2).

And regarding the site of ST-segment depression it was found that the anterior chest leads were the site of ST-segment depression in $6(23 \%)$ patients in group 1 and in $62(83.8 \%)$ patients in group 2, lateral chest leads were $4(15.3 \%)$ in patients in group 1 and in $40(54.1 \%)$ patients in group 2 and the inferior chest leads were the site of ST-segment depression were $3(11.5 \%)$ in patients in group 1 and in $24(32.4 \%)$ patients in group 2 and all these changes were statistically significant ( $p$-value is $<0.001)$.

As regard the site of $\mathrm{T}$-wave inversion, the anterior chest leads were the site of T-wave inversion in $12(66.7 \%)$ patients in group 1 and is 12 $(54.5 \%)$ in group 2 , lateral leads in $10(55.6 \%)$ 
patients in group 1 and in $10(45.5 \%)$ patients in group 2 and the inferior leads in $10(55.6 \%)$ patients in group 1 and in $8(36.4 \%)$ patients in group 2, but none of these differences was statistically significant ( $p$-values $0.44,0.53$ and 0.22 respectively).

Table (2): The ECG findings in the two groups of patients.

\begin{tabular}{|c|c|c|c|c|}
\hline & $\begin{array}{c}\text { Group (1) } \\
n=26\end{array}$ & $\begin{array}{c}\text { Group (2) } \\
n=74\end{array}$ & $\begin{array}{l}\text { Statistical } \\
\text { analysis } \\
\text { result }\end{array}$ & $\begin{array}{c}\text { Sig. } \\
p \text {-value }\end{array}$ \\
\hline Inf. $T$ inv & $10(55.6 \%)$ & $8 \quad(36.4 \%)$ & 1.47 & 0.22 \\
\hline Lat. $\mathrm{T}$ inv & $10(55.6 \%)$ & $10(45.5 \%)$ & 0.4 & 0.53 \\
\hline Ant. $T$ inv & $12(66.7 \%)$ & $12(54.5 \%)$ & 0.61 & 0.44 \\
\hline $\begin{array}{l}\text { Inf ST } \\
\text { depolarization }\end{array}$ & $3(11.5 \%)$ & $24(32.4 \%)$ & 11.1 & $<0.001$ \\
\hline $\begin{array}{l}\text { Lat ST } \\
\text { depolarization }\end{array}$ & $4 \quad(15.3 \%)$ & $40(54.1 \%)$ & 23.42 & $<0.001$ \\
\hline $\begin{array}{l}\text { Ant ST } \\
\text { depolarization }\end{array}$ & $6(23 \%)$ & $62(83.8 \%)$ & 32.59 & $<0.001$ \\
\hline
\end{tabular}

( $t$ ) Is the value of the " $t$-Test".

$\mathrm{x} 2=$ Chi-square value, data are means $\pm \mathrm{SD}$ or No.

- Inf. $\mathrm{T}$ inv $=\mathrm{T}$ wave inversion in inferior leads.

- Lat. $\mathrm{T}$ inv $=\mathrm{T}$ wave inversion in lateral leads.

- Ant. T inv = T wave inversion in anterior leads.

- Inf ST dep = ST-segment depression in lead II, III and avf.

- Lat ST dep = ST-segment depression in V 4, V5, and V6 or I and avl.

- Ant ST dep = ST-segment depression in V1, V2, V3 and V4.

The prevalence of ST-segment elevation in lead aVR in detection of left main coronary artery lesions is $74 \%$.

There were $78.4 \%$ of patients with elevated ST segment. The elevation ranged from $0.5-1$ where $21.6 \%$ of them had an elevation more than 1 , shown in Table (3).

Table (3): The number \& percentage distribution of ST elevation among group 2.

\begin{tabular}{ccc}
\hline \multirow{2}{*}{ ST elevation } & \multicolumn{2}{c}{ Group (2) } \\
\cline { 2 - 3 } & No. & $\%$ \\
\hline $0.5-1 \mathrm{mV}$ & 58 & 78.4 \\
$>1 \mathrm{mV}$ & 16 & 21.6 \\
\hline Total & 74 & 100 \\
\hline
\end{tabular}

Patients with elevated ST segment more than 1 is significantly higher among patients who died than those who still alive $(p<0.001)$ as show in Table (4).

Table (4): The relationship between death \& ST elevation among group 2.

\begin{tabular}{lcccccc}
\hline ST & \multicolumn{2}{c}{ Died } & \multicolumn{2}{c}{ Alive } & \multirow{2}{*}{$X^{2}$} & $\begin{array}{c}p \text { - } \\
\text { elevation }\end{array}$ \\
\cline { 2 - 5 } & No. & $\%$ & No. & $\%$ & & \\
\hline $0.5-1$ & 2 & 25 & 56 & 84.8 & 15.08 & $<0.001$ \\
$>1$ & 6 & 75 & 10 & 15.2 & & \\
\hline Total & 8 & 100 & 66 & 100 & & \\
\hline
\end{tabular}

ST segment elevation has sensitivity $75 \%$ specificity $85 \%$ accuracy $84 \%$ PPV $38 \%$ \& NPN $97 \%$ in detecting cases who will die among all ST segment elevated patients as show in Table (5).

Table (5): Significance of ST segment elevation in detecting patients who will die among all ST segment elevated patients.

\begin{tabular}{ll}
\hline Validity & $\%$ \\
\hline Sensitivity & 75 \\
Specificity & 85 \\
Accuracy & 84 \\
PPV & 38 \\
NPV & 97 \\
\hline
\end{tabular}

4- Cardiac enzymes criteria:

The following peak levels of cardiac enzymes were recorded among the two aVR groups as shown in Table (6):

- Group (1): The mean CK-MB peak level was $70.69 \pm 9.29 \mathrm{IU} / \mathrm{L}$.

- Group (2): The mean CK-MB peak level was 74.72 $13.31 \mathrm{IU} / \mathrm{L}$.

- Normal level of Ck-MB 5 to 25IU/L.

Comparing both groups, there was no statistically significant difference with $p$-value 0.16 as shows in Table (6).

Table (6): Peak CK-MB levels in the two groups.

\begin{tabular}{lcccc}
\hline & $\begin{array}{c}\text { Group (1) } \\
\mathrm{n}=26\end{array}$ & $\begin{array}{c}\text { Group (2) } \\
\mathrm{n}=74\end{array}$ & $\begin{array}{c}\text { Statistical } \\
\text { analysis } \\
\text { result }\end{array}$ & $\begin{array}{c}\text { Sig. } \\
p \text {-value }\end{array}$ \\
\hline $\begin{array}{l}\text { CK-MB peak, } \\
\text { IU/L } \\
(\text { mean } \pm \text { SD) }\end{array}$ & & & & $0.16 \pm 9.29$ \\
$74.72 \pm 13.31$ & $t=1.42$ & 0.16 \\
\hline
\end{tabular}

( $t$ ) Is the value of the " $t$-Test". Data are means \pm SD or No.

\section{5- In-hospital follow-up for major adverse cardiac events (MACE):}

Patients of group 2 had higher prevalence of angina $(78.4 \%)$, heart failure $(3.8 \%)$, reinfarction $(8.1 \%)$ and death $(10.8 \%)$ as shown in Table (7).

Table (7): The In-hospital follow-up for major adverse cardiac events (MACE) in the two groups.

\begin{tabular}{lccccc}
\hline \multirow{2}{*}{$\begin{array}{l}\text { Clinical } \\
\text { finding }\end{array}$} & \multicolumn{2}{c}{$\begin{array}{c}\text { Group 1 } \\
(\mathrm{n}=26)\end{array}$} & \multicolumn{2}{c}{$\begin{array}{c}\text { Group 2 } \\
(\mathrm{n}=74)\end{array}$} & $\begin{array}{c}p- \\
\text { value }\end{array}$ \\
\cline { 2 - 4 } & No. & $\%$ & No. & $\%$ & \\
\hline Angina & 16 & 61.5 & 58 & 78.4 & NS \\
Heart failure & 0 & 0 & 28 & 3.8 & $<0.001$ \\
Reinfarction & 0 & 0 & 6 & 8.1 & NS \\
Death & 0 & 0 & 8 & 10.8 & NS \\
\hline
\end{tabular}




\section{6- Severity of LMNCA disease and ST elevation in} aVR:

Patients were divided according the severity of LMCA lesions to two subgroups: Group (A) had the lesion below $80 \%$ stenosis and another group (B) having the lesion $80 \%$ stenosis or more.

Twenty eight patients (37.8\%) had Left Main coronary disease in group $\mathrm{B}$, less than $80 \%$ stenosis compared to 18 (75\%) patients in group A. While 46 patients $(62,2 \%)$ had Left Main stenosis more than $80 \%$ in group B, compared to 6 patients $(25 \%)$ in group $\mathrm{A}$, the differences between subgroups were statistically significant difference ( $p$-value $<0.001)$ as show in Table (8).

Table (8): Comparison between group A \& group B regarding coronary angiography.

\begin{tabular}{lcccccc}
\hline $\begin{array}{l}\text { Group } \\
\text { LMCA } \\
\text { lesion }\end{array}$ & \multicolumn{2}{c}{$\begin{array}{c}\text { Group 1 } \\
(\mathrm{n}=26)\end{array}$} & \multicolumn{2}{c}{$\begin{array}{c}\text { Group 2 } \\
(\mathrm{n}=74)\end{array}$} & $\mathrm{X}^{2}$ & $\begin{array}{c}p \text { - } \\
\text { value }\end{array}$ \\
\cline { 2 - 5 } & No. & $\%$ & No. & $\%$ & & \\
\hline$<80 \%$ & 18 & 75 & 28 & 37.8 & 10.02 & $<0.001$ \\
$\geq 80 \%$ & 6 & 25 & 46 & 62.2 & & \\
\hline Total & 24 & 100 & 74 & 100 & & \\
\hline
\end{tabular}

\section{Discussion}

Left main coronary artery (LMCA) occlusion is a serious clinical condition. Despite its low incidence, the prognosis is grave. It may present as sudden death, complete heart block, shock and/or acute coronary syndrome (ACS). Surgery is usually too late to initiate, so that percutaneous coronary intervention (PCI) is utilized to obtain immediate vessel patency. However, this modality is associated with a high mortality and restenosis rate. Early recognition and emergent PCI may be lifesaving [2].

The electrocardiogram (ECG) is sensitive and valuable for detecting ACS. It showed ST elevation in patients with acute STEMI and horizontal ST depression in those with acute NSTEMI. However lead aVR is a mostly ignored but very valuable lead in ACS [7].

Because patients with NSTEMI are heterogeneous with respect to the pathophysiological mechanisms, the size of the infarction, and the amount of jeopardized myocardium, early risk stratification is a fundamental step in the management of this condition $[8,9]$.

- The current study was performed on 100 patients with left main coronary artery stenosis and suffered NSTEMI.
- The current study found that $74 \%$ of the patients with left main lesion had ST elevation in aVR lead (58\% had elevation from 0.5-1 and 16\% had elevation $>0.1 \mathrm{mv}$ ) while $26 \%$ didn't have ST elevation.

In a study performed by Hengrussamee Kehasukcharoen et al., study, [10] ST elevation in lead aVR was $60 \%$ in Left main group. In Taglieri et al. (2011) study [11], found ST elevation in lead aVR in $90.2 \%$ of left main coronary artery group . In a study by Barrabes et al. (2003) [4], 9 patients had left main coronary artery lesion, 7 had ST segment elevation in lead aVR (77.7\%). Yamaji et al. (2001) [7], showed that ST elevation in aVR more than $0.5 \mathrm{mv}$ is present in $88 \%$ of patients with acute left main obstruction. Nough et al. (2012) [12], found that $40.7 \%$ of men and $43.8 \%$ of women with left main coronary artery lesion had ST segment elevation $>0.1 \mathrm{mv}$.

The current study found that male sex is significantly higher among patients with elevated ST segment in avR lead than those with no elevation.

Barrabes et al. (2003) [4], found that ST elevation in lead aVR was significantly higher in males. In contrary Barrabes et al. (2003) [4] found that active smoking, diabetes are more common in patients with ST elevation, while dyslipidemia and hypertension were statistically insignificant. Nough et al. (2012) [12], found that the ECG pattern was statistically similar in diabetics and nondiabetics, hypertensives and normotensives, in smokers and non-smokers and hyperlipidemic and normolipidemic patients. And regarding the site of ST-segment depression the study revealed highly statistically significant difference in all, anterior, lateral and inferior chest leads in the aVR group with ST segment elevation compared to the other group of patients with ( $p$-value <0.001) for all.

These results were also similar to those of Barrabes et al. (2003) [4] who showed highly statistically significant difference in all, anterior, lateral and inferior chest leads in the aVR elevated group with ( $p$-values >0.001).

The patients with ST segment elevation in lead aVR in NSTEMI had no statistically significant difference as regard the presence of T-wave inversion. In Barrabes et al. (2003) [4], study, the same finding was observed where there was lower frequency of T-wave inversion in the patients with ST segment elevation in lead aVR in NSTEMI than the remaining patients.

The present study found that there was no significant difference between the mean peak value 
of CK MB in patients with ST elevation in aVR and those without and this coincides with Barrabes et al. (2003) [4]. The lack of association between ST-segment elevation in lead aVR and peak CKMB levels makes it unlikely that its adverse prognostic significance was dependent on a larger infarct size.

Our study found that heart failure as a clinical finding was significantly prevalent among patients with ST elevation in aVR lead which coincides with Barrabes et al. (2003) [4], who found that ST segment elevation in aVR was strongly associated with heart failure.

The present study found that ST elevation $>0.1 \mathrm{mv}$ is significantly higher in patients who died than those who stayed alive.

The current study considered smoking, dyslipidemia, diabetes, hypertension and positive family history as risk factors for ACS and found that dyslipidemia was significantly more frequent among patients with elevated ST segment than those with normal ST segment.

Yamaji et al. (2001) [7], found that death occurred more frequently in patient with higher ST segment elevation in lead aVR than those with less severe elevation. Barrabes et al. (2003) [4], found that in-hospital mortality increased in a stepwise fashion across increasing categories of ST elevation in lead aVR and this was the only variable from the initial ECG that was retained as a $n$ independent predictor of death.

The present study ST segment elevation has a sensitivity of $75 \%$, a specificity $85 \%$, accuracy $84 \%$ and a positive predictive value of $38 \%$ and a negative predictive value of $97 \%$ in detecting cases who will die. Yamaji et al. (2001), when ST segment elevation of 0.15 was used as a cut off value death was predicted with $75 \%$ sensitivity, $75 \%$ specificity and $75 \%$ accuracy.

The present study found that ST elevation in lead aVR was associated with more severe coronary artery lesion and this coincides with Barrabes et al. (2003) [4].

The present study found that para-osteal lesions are more prevalent than osteal lesions among left main coronary artery occlusion. Yildirimturk et al. (2011) [13] also found a similar result mentioning that left main coronary artery narrowing mostly occurs beyond the ostium in the mid portion or at the bifurcation where it can extend to both major branches. The present study also found that osteal lesions were more common in females as compared to males.

Yildirimturk et al. (2011) [13], found that female gender were more prominent in osteal left main coronary artery group. He explained that one reason for female predominance might be related to LMCA anatomy. The caliber of LMCA varies according to the gender and the size of the individual [14] The LMCA size varies, with an average diameter of $4.5 \pm 0.5 \mathrm{~mm}$ in men and $3.9 \pm 0.4 \mathrm{~mm}$ in women. Irrespective of body surface area, the LMCA is smaller in women than in men [15]

Yamanaka and Hobbs (1993) [16] reported that women were more prominent among subjects with ostial stenosis. They believed that menopausal decline in estrogen may have a role in its pathogenesis. Mahajan et al. (2006) [17] also reported a trend suggestive of a higher incidence of ostial lesions among women $(63 \%$ versus $31 \%, p=0.06)$.

Electrocardiographic lead aVR is usually ignored in patients with chest pain. ST segment elevation in aVR may have diagnostic value in patients with acute coronary syndrome (ACS) and significant stenosis or obstruction of the left main coronary artery (LMCAS), especially when accompanied by ST segment elevation in lead V. In patients with LMCAS, ST segment elevation in lead aVR was two times more frequent than in remaining patients, whereas there were no differences in lead $\mathrm{V}[\mathbf{1 8 , 1 9 ]}$.

It represents abnormalities of the right upper side of the heart (right ventricular outflow tract) and basal part of the interventricular septum. Lead aVR can inform reciprocal changes from the left lateral side covered by lead aVL, II, V5 and V6 [20].

ST segment elevation in lead aVR determined myocardial ischemia or infarction of the basal part of the interventricular septum and culprit coronary lesions in patients with acute coronary syndrome (ACS). Those lesions are acute left main occlusion, proximal left anterior descending artery occlusion and 3-vessel coronary artery disease [7].

\section{Recommendations:}

\section{From this study, we recommend:}

1- Using changes in lead aVR in risk stratification of cases with NSTEMI, directing more attention to the patients at more risk and referral of these cases to the highly specialized centers as soon as possible for invasive approach if needed in order to achieve best outcome. 
2- Further studies are recommended to investigate the prognostic value of ECG in general and of lead aVR in particular.

\section{References}

1- TORRES M. and MOAYEDI S.: Evaluation of the acutely dyspneic elderly patient. Clinics in Geriatric Medicine, 23 (2): p. 307-325, 2007.

2- LEE W.-C., et al.: Safety and feasibility of coronary stenting in unprotected left main coronary artery disease in the real world clinical practice-a single center experience. PloS One, 9 (10): p. e109281, 2014.

3- MENOWN I. and ADGEY A.: Improving the ECG classification of inferior and lateral myocardial infarction by inversion of lead aVR. Heart, 83 (6): p. 657-660, 2000.

4- BARRABÉS J.A., et al.: Prognostic value of lead aVR in patients with a first non-ST-segment elevation acute myocardial infarction. Circulation, 108 (7): p. 814-819, 2003.

5- PANOVSK'Y R., et al.: The ergometry stress test in patients with stenosis of the left main coronary artery. Vnitrni lekarstvi, 43 (10): p. 659-662, 1997.

6- CALIFF R.M., et al.: "Left main equivalent" coronary artery disease: Its clinical presentation and prognostic significance with nonsurgical therapy. American Journal of Cardiology, 53 (11): p. 1489-1495, 1984.

7- YAMAJI H., et al.: Prediction of acute left main coronary artery obstruction by 12-lead electrocardiography: ST segment elevation in lead aVR with less ST segment elevation in lead V 1. Journal of the American College of Cardiology, 38 (5): p. 1348-1354, 2001.

8- BRAUNWALD E., et al.: ACC/AHA 2002 guideline update for the management of patients with unstable angina and non-ST-segment elevation myocardial infarction-summary article: A report of the American College of Cardiology/American Heart Association task force on practice guidelines (Committee on the Management of Patients With Unstable Angina). Journal of the American College of Cardiology, 40 (7): p. 1366-1374, 2002.

9- AMSTERDAM E.A., et al.: 2014 AHA/ACC guideline for the management of patients with non-ST-elevation acute coronary syndromes: A report of the American College of Cardiology/American Heart Association Task Force on Practice Guidelines. Journal of the American College of Cardiology, 64 (24): p. e139-e228, 2014.
10- HENGRUSSAMEE K., KEHASUKCHAROEN W. and TANSUPHASWADIKUL S.: Significance of lead aVR ST segment elevation in acute coronary syndrome. JournalMedical Association of Thailand, 88 (10): p. 1382, 2005.

11- TAGLIERI N., et al.: Short-and long-term prognostic significance of ST-segment elevation in lead aVR in patients with non-ST-segment elevation acute coronary syndrome. The American journal of cardiology, 108 (1): p. 21-28, 2011.

12- NOUGH H., et al.: The value of ST-segment elevation in lead aVR for predicting left main coronary artery lesion in patients suspected of acute coronary syndrome. Romanian journal of internal medicine $=$ Revue roumaine de Medecine Interne, 50 (2): p. 159-164, 2012.

13- YILDIRIMTURK O., et al.: Coexistence of left main and right coronary artery ostial stenosis: Demographic and angiographic features. The International journal of angiology: official publication of the International College of Angiology, Inc., 20 (1): p. 33, 2011.

14- DODGE J.T., et al.: Lumen diameter of normal human coronary arteries. Influence of age, sex, anatomic variation, and left ventricular hypertrophy or dilation. Circulation, 86 (1): p. 232-246, 1992.

15- CLEMENS VON BIRGELEN M., et al.: Variations of remodeling in response to left main atherosclerosis assessed with intravascular ultrasound in vivo. The American Journal of Cardiology, 80 (11): p. 1408-1413, 1997.

16- YAMANAKA O. and HOBBS R.E.: Solitary ostial coronary artery stenosis. Japanese Circulation Journal, 57 (5): p. 404-410, 1993.

17- MAHAJAN N., et al.: Isolated and significant left main coronary artery disease: Demographics, hemodynamics and angiographic features. Angiology, 57 (4): p. 464-477, 2006.

18- ROSTOFF P., et al.: Value of lead aVR in the detection of significant left main coronary artery stenosis in acute coronary syndrome. Kardiologia Polska (Polish Heart Journal), 62 (2): p. 132-135, 2005.

19- ROSTOFF P. and PIWOWARSKA W.: Original Article ST segment elevation in lead aVR and coronary artery lesions in patients with acute coronary syndrome. Kardiologia Polska (Polish Heart Journal), 64 (1): p. 8-14, 2006.

20- HURST J.W.: Methods used to interpret the 12-lead electrocardiogram: Pattern memorization versus the use of vector concepts. Clinical Cardiology, 23 (1): p. 4-13, 2000. 


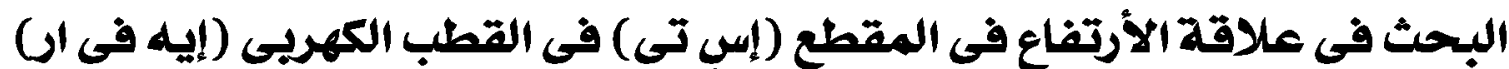

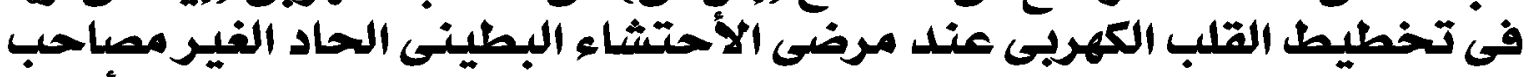

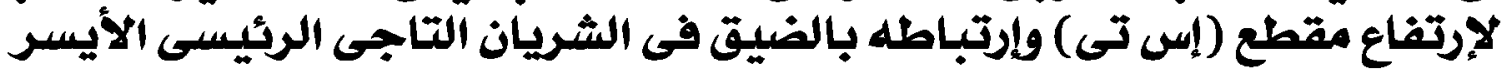

يعتبر تخطيط القلب الكهربى من الطرق السهلة السريعة والمتاحة لتقييم الخطوة لدى مرضى قصقد الشرايين. الهدف من هذا البحث: هو استكثاف إمكانية إستخدام إرتفاع المقطع ST فى القطب الكهربى aVR كطريقة سبهلة لتصنيف مرضى القصود وتحديد طريقة علاجهم. احتوت الدراسة على . .1 مريض يشعر بالّام الذبحة الصدرية لاكثر من عشرين دقيقة مع إرتفاع ملحوظ فى إنزيمات القلب. وقد تم تقسيمهم إلى مجموعتين طبقاً للارتفاع فى المقطع ST فى القطب الكهربى aVR:

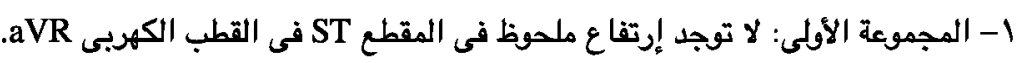

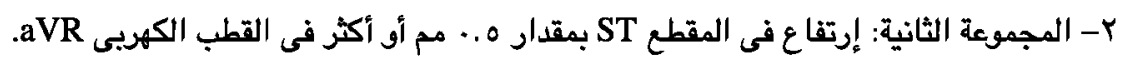
ويستنى من هذا البحث كل المرضى اللذين كان لديهم ارتفاع فى المقطع ST فى أى قطب عدا aVR أو انقطاع بالضفيرة الكهربية اليسرى.

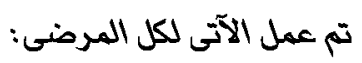

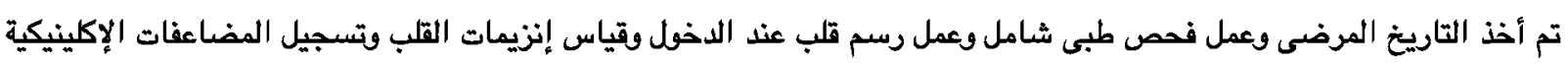
وعمل قسطرة قلبية تشخيصية فى خلال شهر من تاريخ الدخول.

وقد خلص البحث إلى النتائج التالية:

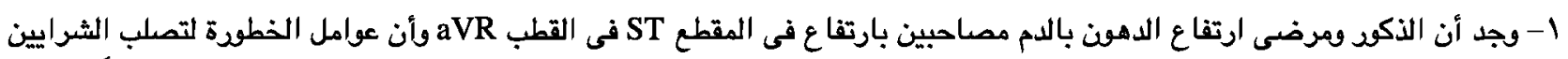

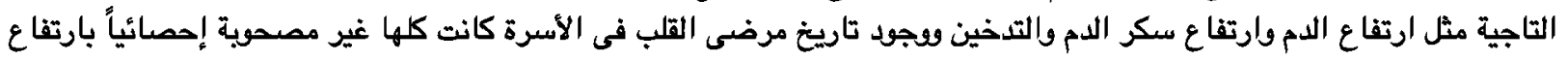

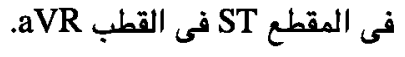

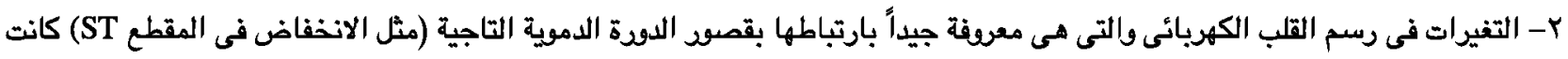

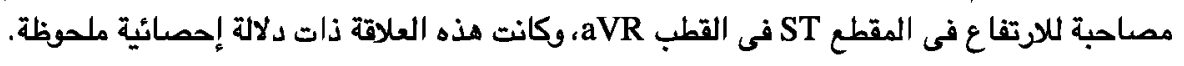

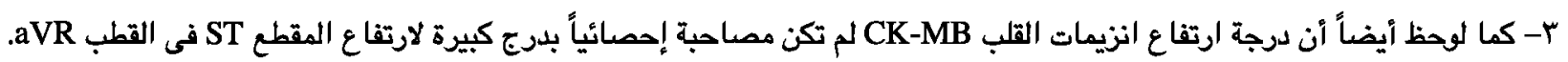

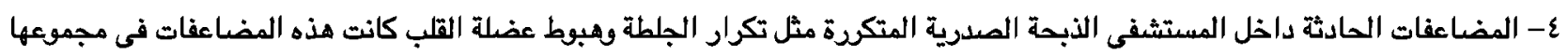

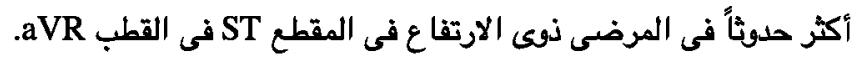
ونخلص من ذلك إلى أن استخدام الارتفاع فى المقطع ST فى القطب aVR (رغم كونه ههملاً من قبل) هى طريقة جديدة وحساسة جداً

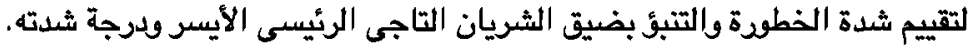
كما نوصى بمزيد من الدراسات لبحث هذه النقطة فى تجارب أخرى على أعداد أكبر من المرضى وفى نوعيات أخرى من مرضى قصود 